\title{
Professzionális magyar jégkorongozók személyiségének, megküzdési stratégiáinak és megélt stressz-szintjének vizsgálata
}

\section{Examination of Hungarian professional ice hockey players' personality, coping strategies and stress level}

\section{Tóth Renátó1,Szabó Kinga²}

\begin{abstract}
1 Budapesti Múszaki és Gazdaságtudományi Egyetem, Gazdaság- és Társadalomtudományi Kar, Ergonómia és Pszichológia Tanszék, Budapest

2 Babes-Bolyai Tudományegyetem, Pszichológia és Neveléstudományok Kar, Alkalmazott Pszichológia Intézet, Kolozsvár
\end{abstract}

Absztrakt - A tanulmány fó célja feltárni bizonyos pszichológiai jelenségek (személyiség, megküzdési stratégiák, stressz) szerepét a hivatásos magyar profi jégkorongozók körében. A kutatás során az online kérdőíves eszközcsomagot 65 hivatásos magyar jégkorongozó töltötte ki. Az eredmények alapján megállapítható, hogy bizonyos személyiségjegyek (neuroticitás, extraverzió, lelkiismeretesség) központi szerepet töltenek be a sportolók stressz-szintjére, valamint regenerációjára nézve. Továbbá bebizonyosodott, hogy különbség van különböző stressz-szinttel rendelkezó jégkorongozók megküzdési képességei között. Összességében ezeknek az adatoknak a tükrében sikerült olyan következtetéséket levonni, amelyek hozzájárulhatnak a sportolók eredményesebb és sikeresebb teljesítményéhez. Továbbá számos továbbfejlesztési lehetőséget tesz lehetóvé a tanulmány, mint például egyéb sportág képviselőinek a bevonását a kutatásba és az eredmények összehasonlítását.

Kulcsszavak: sportpszichológia, jégkorong, személyiség, megküzdési képességek, stressz

Abstract - The aim of this study was to investigate the effect of personality traits and coping strategies on stress among professional Hungarian ice hockey players. Data were collected online from $\mathrm{N}=65$ professional players. Results of the linear regression analysis show that personality traits (neuroticism, extraversion, conscientiousness) have a significant effect on the players' stress level and regeneration. Furthermore, there were differences between players with low and high levels of stress in sport specific coping strategies. The findings should be applied in training and coaching of hockey players in order to facilitate their sport performance. Further results and implications are discussed.

Keywords: sport psychology, ice hockey, personality, coping strategies, stress

\section{Bevezetés}

Napjainkban egyre inkább kulcsfontosságúvá válik a fizikai felkészülés mellett a mentális felkészültség. A professzionális sport terén kezd evidensé válni, hogy a sikeresség és az eredményesség elengedhetetlen tényezője a megfelelő pszichológiai állapot elérése és fenntartása a versenyzés során. A sportpszichológia, mint tudomány, nagyon sok pszichológiai konstruktumot foglal magában, ilyen például a stressz, a személyiség vagy a megküzdési stratégiák. Az imént kiemelt három tényező (stressz, személyiség, megküzdési stratégiák) alkotja jelen tanulmány központi témáját. Kutatásunk során hivatásos magyar profi jégkorongozókat vizsgáltunk Ennek a sportágnak a képviselőit még nagyon kevesen tanulmányozták hazánkban, és a sportágban kevés sportpszichológiai szakember tevékenykedik. Jelen tanulmány megpróbálja az eredmények segítségével hangsúlyozni a pszichológia meghatározó 
szerepét a jégkorongban. Tanulmányunk fö célkitűzése feltárni, hogy a hivatásos magyar profi jégkorongozók személyiségjegyei milyen hatással vannak a stresszre, valamint felszínre hozni a sportspecifikus megküzdési stratégiákat és ezeket összehasonlítani az átlagon aluli és felüli stressz-szinttel rendelkező jégkorongozóknál. Ezenfelül szeretnék segítséget nyújtani a kutatás során kapott eredményekkel azon szakemberek számára, akik a sport e területén végzik a munkájukat.

\section{Stressz és a személyiség kapcsolata a sportban}

Általában két ellentétes stressz formát különböztünk meg: az eustresszt, valamint a distresszt. Az eustressz segít elérni a magunk elé kitűzött célokat, valamint segíti a maximális teljesítmény elérését azáltal, hogy pozitív energiát és motivációt generál. Ez azzal indokolható, hogy ez az állapot egyfajta optimális stressz-szintet hoz létre, amit optimális arousal szintnek nevezünk. Ez fontos szerepet játszik a megfelelő teljesítmény és hatékonyság elérésében (Aamodt, 2010). Az eustressz ellentéte a distressz, ami akkor jelenik meg, ha az egyénben túl magas a stressz-szint és nem tudja csökkenteni vagy megszüntetni azt. Előfordulását tekintve a leggyakrabban azokban az esetekben jelenik meg, amikor az egyén számára jelentős esemény az önbefolyáson kívül esik. Ez az állapot, továbbá, akkor is megmutatkozhat, ha egyensúlyhiányt tapasztalunk az elénk állított követelmények, illetve saját képességeink között.

Selye (1950) a stressz három szakaszát különíti el, amit általános adaptációs szindrómának (GAS: General Adaptation Syndrome) nevezett el. Az első szakasz az alarm reakció, ami egy olyan készenléti állapot, amely a stresszre adott választ, és a stresszhelyzetre való felkészülést jelenti. Két módját különböztetjük meg: a menekülést vagy a szembeszállást („flight or fight”) a stresszorral. Ez a szakasz általában együtt jár különböző vegetatív változásokkal, mint például a felgyorsult szívverés és légzés vagy a kitágult pupillák. A második szakasz az alkalmazkodás, ellenállás, ahol már állandósulnak a szervezetben létrejövő problémák (pl.: alvászavar, magas vérnyomás, zavart bélműködés). Egy személy abban az esetben kerül ebbe a szakaszba, ha nem képes ellenállni a stresszornak és a szervezet kénytelen fenntartani a védekezést, valamint, ha megpróbál alkalmazkodni ehhez az állapothoz. A harmadik szakasz során már elfogynak a szervezet tartalékai és elöször megbetegszik a személy, majd egyre súlyosabb egészségügyi problémái lesznek, ezért is nevezik ezt az állapotot kimerülésnek.

Fontossá vált ezen jelenség kutatása a sportolók körében is, egyrészt, mert a stressz-szint kihat nemcsak a sportolók teljesítményére, másrészt pozitív kapcsolatot mutattak ki a magas stressz-szint és sport sérülések között (Maddison és Prapavessis, 2005).

A stressz és az azzal való megküzdést vélhetően több tényező is befolyásolhatja. Ilyen például az életkor. Géczi, Bognár, Tóth, Sipos és Fügedi (2008) vizsgálatukban arra a megállapításra jutottak, hogy a felnőtt válogatott jégkorongozók alacsonyabb kognitív és szomatikus szorongást mutatnak, mint az U18-as válogatott tagjai. Ez azzal magyarázható, hogy az idősebb sportolók jobban tudják kezelni a váratlan stresszhelyzeteket. Az élsportolók eredményességét nagyban meghatározza az optimális arousal szint, valamint a stresszhelyzetekre adott megfelelő reakciók és ezekben a folyamatokban az idősebb professzionális sportolók általában jobb értékeket mutatnak, mint a fiatalabb társaik (Tóth, Géczi, Sipos és Bognár, 2010).

A személyiséget tekintve kutatásunk során a széles körben elterjedt ötfaktoros személyiség modellt használjuk elméleti alapként. Az ötfaktoros modellt Goldberg (1990) fogalmazta meg elsőként, amit később Costa Jr. és McCrae (2003) validált minden korosztály számára. Ez az 5 faktort (neuroticitás, nyitottság, extraverzió, együttműködés, lelkiismeretesség) foglal magában, reprezentálja leginkább a személyiség alapvető tényezőit (Costa Jr. és McCrae, 1992).

Több tudományos tanulmány is megerősítette, azt a feltevést, miszerint a személyiségjegyek fontos szerepet töltenek be a stressz azonosításában és a stresszre adott válaszokban (Dumitru és Cozman, 2012). Továbbá bizonyítást nyert az is, hogy bizonyos személyiségjegyek előre jelezhetik a stresszszintjét (Afshar, Roohafza, Keshteli, Mazaheri, Feizi, Adibi, 2015). Az ötfaktoros modellt alapul véve, azt találták, hogy a neuroticizmus növelheti a stresszt, míg az adaptívabb személyiségjegyek (pl. extraverzió, lelkiismeretesség) pozitív hatással lehetnek a stresszre (Magnus, Diener, Fujita, Pavot, 1993).

A fent említett kutatásokból jól látható, hogy a személyiségjegyek hatással vannak a mindennapi stresszre, azonban jelen tanulmány egyik fó kérdése, hogy a professzionális jégkorongozóknál ez az 
összefüggés hogyan alakul, milyen hatással vannak a személyiségtényezők a stresszre. Piedmont, Hill és Blanco (1997) kutatásukban személyiség és a sportteljesítmény összefüggéseit vizsgálták az ötfaktoros személyiség modellel $\mathrm{N}=79$ női labdarúgó esetében. Eredményeik azt mutatják, hogy a neuroticitás negatív, a lelkiismeretesség pedig pozitív szignifikáns összefüggést mutat a sportteljesítménnyel. Véleményük szerint az alacsony neuroticitás és a magas lelkiismeretség lehet a legjobb kombináció egy sportolónál, hiszen az ilyen személyiségkombinációval rendelkező sportolók képesek megtenni a legtöbbet a céljaik elérése érdekében (Piedmont és mtsai, 1997).

\section{Megküzdési stratégiák definiálása és jelentö- sége a sportban}

A sportolói eredményesség és a sikeresség elengedhetetlen része a téthelyzetekben való pszichológiai stabilitás, ami magába foglalja a stresszel való megküzdést, hiszen egy kiélezett verseny során a sportolók nagyon gyakran találkoznak stresszkeltő szituációkkal. Lazarus és Folkman (1984) szerint amint az egyén,olyan helyzetbe kerül, amit ő stresszkeltőnek érzékel, elindul a megküzdési folyamat, ami a stresszkeltő szituáció kiértékelésén alapszik. Ez a sportolók esetében sincs másképp, különböző megküzdési stratégiákat használva, megkísérlik kezelni a feszült, stresszes, negatív helyzeteket (Kristiansen, Murphy és Roberts, 2012). Ha egy sportoló versenyzés közben egy szituációt stresszesnek él meg, akkor elkezdődik a streszszel való megküzdés, amelynek módja nagyban befolyásolja a sportoló teljesítményét. Sportolók esetében általában megkülönböztetünk sport-specifikus megküzdési stratégiákat, ilyen például a koncentráció, szorongásmentesség vagy a nyomás alatti teljesítmény (Crocker, Tamminen, Gaudreau, 2015). Ezeknél a megküzdési képességeknél adódhatnak különbségek sportolók között, amelyek hatással lehetnek a teljesítményükre. Anshel és Anderson (2002) megállapították, hogy a helytelen megküzdési módok teljesítménybeli deficithez vezethetnek.

Novotny és Petrak (1983) megállapította, hogy a magasabban jegyzett ligákban játszó jégkorong játékosok mentálisan stabilabbak. Továbbá Orlick és Pattrington (1988) szerint a sikeresebb jégkorongozókat a nyomás alatti jó teljesítmény jellemzi, tehát ennek a megküzdési képességnek magas a pontszáma. Sági, Velenczei és Géczi (2012) 25-25 fiú birkózót $(M=17,28)$ és jégkorongozót $(\mathrm{M}=16,96)$ vizsgáltak és arra a megállapításra jutottak, hogy a legjellemzőbb stratégia a célkitűzés/ mentális felkészülés volt, míg a legkevésbé jellemző értéket a szorongásmentesség mutatta mindkét sportág esetében. A sportolók megküzdési stratégiái és életkora között is fedezhető fel összefüggés. Ezt bizonyítja Nicholls, Polman, Morley és Taylor (2009) kutatása, akik megállapították, hogy jelentős különbség van a különböző életkorú és pubertáskorú sportolók megküzdési módszerében, valamint a megküzdési stratégiák hatékonyságában is. Ezeket az eredményeket Kyprianou, Sipos és Stravros (2009) kutatása is alá tudja támasztani, hiszen bebizonyították, hogy a serdülőkorú sportolók a felnőttekhez viszonyítva gyengébb teljesítményt mutatnak a koncentrációval és a sporttal kapcsolatos körülményekkel történő megküzdésben.

\section{A kutatás céljai és hipotézisei}

Jelen kutatás célja megállapítani, hogy a hivatásos profi magyar jégkorongozók személyiségjegyei milyen hatással vannak a stresszre és a regenerációra, valamint hogy a megküzdési stratégiáik milyen eredményt mutatnak különböző stressz-szinttel rendelkező jégkorongozók esetében. Két hipotézist vizsgáltunk: a neuroticitás negatívan, míg az adaptív személyiségjegyek (extraverzió, lelkiismeretesség, nyitottság) pozitívan jelzik előre a hivatásos magyar jégkorongozók stressz állapotát (H1), Különbség van az átlagon aluli és átlagon felüli általános és sport-specifikus stressz-szinttel rendelkező sportolók megküzdési stratégiái között $(\mathrm{H} 2)$.

\section{Minta és módszerek}

\section{A vizsgálatban résztvevö személyek}

A kutatásban résztvevő személyek $(\mathrm{N}=65)$ hivatásos profi szerződéssel rendelkező olyan jégkorongozók, akik magyarországi székhelyü profi klubok (magyar bázisú ERSTE Liga, szlovák bázisú TIPOS Extraliga, osztrák bázisú ICE Hockey League) magyar állampolgársággal rendelkező hivatásos játékosai.

Ahogy az 1. ábra. is szemlélteti a legfiatalabb kitöltő 17 éves volt, míg a legidősebb $30(\mathrm{M}=21,75$, $\mathrm{SD}=2,75) .17$ és 30 év között minden életkorból volt legalább egy kitöltő, kivéve 26 évnél (lásd: 1. ábra.). 


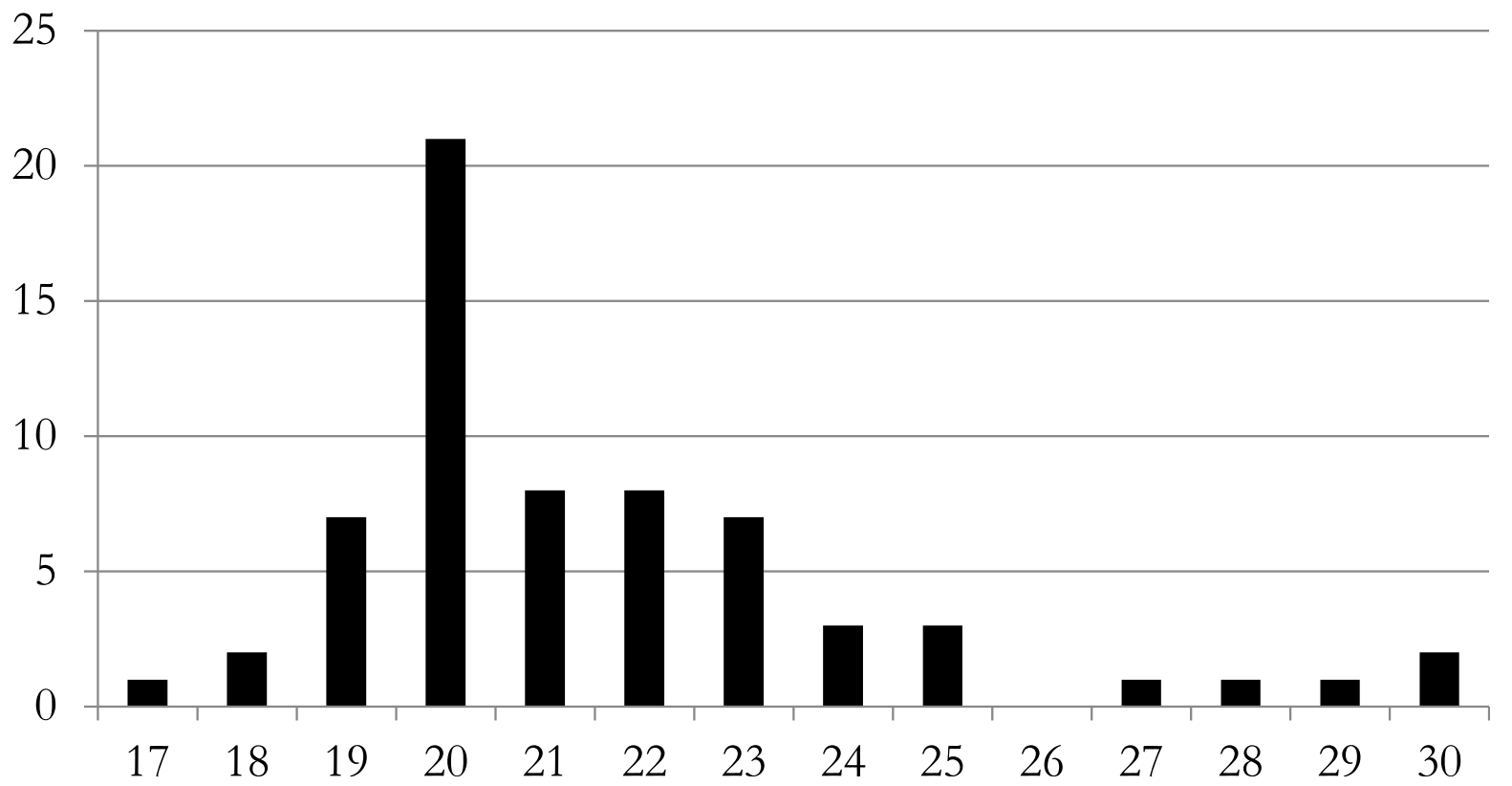

1. ábra. Életkor szerinti eloszlás (Forrás: saját szerkesztés)

Az adatfelvétel és az adatfeldolgozás módszerei

A kutatás során kérdőívekkel mértük a különböző pszichológiai konstruktumokat, amelyeket online platformon juttattunk el a hivatásos, profi szerződéssel rendelkező magyar jégkorongozókhoz. A kérdőív csomag első oldalán a következő információk voltak feltüntetve: „a vizsgálatban való részvétel teljesen önkéntes, bármikor megszakítható, az adatokat csak is tanulmányi céllal használjuk fel és azokat teljesen anonim módon kezeljük”. Ezzel biztosítva a kitöltőket afelől, hogy az adataik csakis a jelen kutatásban kerülnek feldolgozásra, illetve, hogy személyük vizsgálatban nem beazonosítható. A kérdőívek kitöltése körülbelül 30 percet vett igénybe.

Kutatásunk során többszörös lineáris regreszsziót és nem parametrikus Kruskal-Wallis próbát alkalmaztunk az adataink feldolgozásához. A többszörös lineáris regresszió választ ad arra, hogy a független változók változása milyen hatással van a függő változóra, valamint megmutatja a független változóknak a függő változóra vonatkozó előrejelző hatását. A Kruskal-Wallis próba azt vizsgálja, hogy két külön csoportban az átlagok szignifikánsan eltérnek-e egymástól (Szokolszky, 2004).

\section{A kutatás során használt eszközök}

A sportolók stressz-szintjét Recovery-Stress Questionnaire for Athletes (RESTQ-Sport) kérdőívvel mértük, amelyet Kallus és Kellmann (2001) hozott létre annak érdekében, hogy mérhetővé tegyék a sportolók stressz és regeneráció szintjét. Négy faktort vizsgál az eszköz: általános stressz, általános regeneráció, sport-specifikus stressz, sport-specifikus regeneráció. A RESTQSport 24 itemet tartalmaz, amelyek mindegyikére a vizsgálati személyeknek a 7 pontos Likert-skálán (0=soha, 1=Ritkán, 2=Időközönként, 3=Gyakran, 4=Elég Gyakran, 5=Nagyon Gyakran 6=Mindig) kell kiválasztaniuk az elmúlt három napban rájuk legjellemzőbb válaszlehetőséget. Az eszköz érvényességét és megbízhatóságát a fejlesztők bizonyították (Kallus és Kellmann, 2001). A kérdőív végső magyar változatát oda-vissza fordítás technikájával alakítottuk ki.

A személyiségjegyeket NEO Five-Factor Inventory rövidített ötfaktoros személyiség kérdőívvel mértük. Ez a fajta ötfaktoros személyiség kérdőív első változata az úgynevezett NEO PI-R volt, amelyet 1978-ban Costa és McCrae fejlesztett ki (Costa és McCrae, 2008). Háromszor vizsgálták felül és frissítették a modellt, valamint készítettek egy rövidített változatot is, amelynek a neve a NEO-FFI (NEO Five-Factor Inventory). $\mathrm{Ez}$ a változat 60 itemet tartalmaz, minden faktorhoz 12 item tartozik és ötpontos Likert-skálán (1: egyáltalán nem ért egyet az állítással, egyértelműen hamis, 5: erősen egyetért az állítással, 
egyértelműen igaz) kell válaszolniuk a kitöltőknek, annak függvényében, hogy mennyire értenek egyet vagy sem az adott állítással. A következő öt személyiségjegyet tartalmazza: neuroticitás, extraverzió, nyitottság, együttműködés és lelkiismeretesség. A fejlesztőknek többször is sikerült bizonyítaniuk az eszköz megbízhatóságát és érvényességét (Costa és McCrae, 2008).

A sportolók megküzdési képességeit az Athletic Coping Skills Inventory-28 (Smith, Schutz, Smoll és Ptacek, 1995) kérdőív alapján mértük fel. A kérdőívnek (Athletic Coping Skills Inventory, rövidítve ACSI) első változatát az 1980-as évek közepén fejlesztették ki egy olyan kutatási projekt keretein belül, ahol a pszicho-szociális sérülékenység és rugalmasság, valamint a sportolói sérülések kapcsolatát vizsgálták. Később az eredeti 87 itemet 42re csökkentették, amely 8 faktort tartalmazott. A modell végső formája 28 itemes lett, ennek a neve Athletic Coping Skills Inventory-28 (ACSI-28).
Ez egy többdimenziós skálát tartalmazó 7 megküzdési képességet mérő magas faktoriális érvényességű verzió. A következő 7 faktort tartalmazza: kudarccal való megküzdés, edzhetőség, koncentráció, magabiztosság és teljesítménymotiváció, célok megfogalmazása és mentális felkészültség, nyomás alatti teljesítmény, szorongásmentesség. Jelen kutatás során a 28 itemes verziót használjuk, amelynek végső magyar változatát oda-vissza fordítás technikájával kaptuk meg.

\section{Eredmények bemutatása és értelmezése}

\section{A kutatás fóbb változóinak vizsgálata}

A hivatásos magyar jégkorongozók stressz állapotát a Recovery-Stress Questionnaire Sport (RESTQ-Sport) kérdőívvel mértük, amely négy faktort tartalmazott: általános és sport-specifikus stressz, valamint általános és sport-specifikus regeneráció.

1. táblázat. A RESTQ-Sport stressz kérdőívben kapott alskálák eredményeinek a leíró statisztikája és reliabilitása

\begin{tabular}{|c|c|c|c|c|c|c|c|}
\hline Változó & $\mathbf{N}$ & Min. & Max. & Átlag & Szórás & Itemek & $\begin{array}{c}\text { Megbízhatósági } \\
\text { mutató }\end{array}$ \\
\hline Általános stressz & 65 & 2 & 22 & 13,52 & 4,50 & 4 & 0,75 \\
\hline $\begin{array}{c}\text { Általános } \\
\text { regeneráció }\end{array}$ & 65 & 1 & 18 & 11,60 & 3,38 & 3 & 0,65 \\
\hline $\begin{array}{c}\text { Sport-specifikus } \\
\text { stressz }\end{array}$ & 65 & 4 & 24 & 15,97 & 4,15 & 4 & 0,68 \\
\hline \begin{tabular}{c} 
Sportregeneráció \\
\hline
\end{tabular} & 65 & 18 & 48 & 32,72 & 7,22 & 8 & 0,87 \\
\hline
\end{tabular}

Az első táblázatban bemutatott adatok alapján elmondható, hogy az általános regeneráció esetében minden adat (minimum, maximum, átlag, szórás) a legkisebb, azonban észrevehető az is, hogy ehhez a skálához csak 3 item tartozik, ami azzal magyarázható, hogy az általános regeneráció esetében az egyik itemet kizártuk, hiszen ennek hatására a Cronbach-alfa (megbízhatósági mutatót) 0,56-ról 0,65-re emelkedett.

A személyiséget egy rövidített ötfaktoros kérdőivel (NEO-FFI) mértük, amely a Big Five modell öt faktorát tartalmazza: neuroticitás, extraverzió, nyitottság, együttműködés, lelkiismeretesség. 
2. táblázat. A NEO-FFI ötfaktoros személyiségteszt eredményeinek leíró statisztikája és reliabilitása

\begin{tabular}{|c|c|c|c|c|c|c|c|}
\hline Változó & N & Min. & Max. & M & SD & Itemek & $\begin{array}{c}\text { Megbízható- } \\
\text { sági mutató }\end{array}$ \\
\hline Neuroticitás & 65 & 12 & 45 & 30,02 & 7,28 & 12 & 0,80 \\
\hline Extraverzió & 65 & 29 & 52 & 41,38 & 4,49 & 12 & 0,52 \\
\hline Nyitottság & 65 & 24 & 47 & 35,52 & 5,45 & 12 & 0,60 \\
\hline Együttmúködés & 65 & 33 & 53 & 41,71 & 5,01 & 12 & 0,62 \\
\hline Lelkiismeretesség & 65 & 31 & 60 & 47,86 & 6,01 & 12 & 0,81 \\
\hline
\end{tabular}

A második táblázatból adatai alapján meg tudjuk állapítani, hogy az öt faktor közül a profi jégkorongozókra leginkább jellemző személyiségjegy a lelkiismeretesség, míg legkevésbé jellemző a neuroticitás.
A megküzdési stratégiákat az Athletic Coping Skills Inventory nevü sportolói megküzdés kérdőívvel vizsgáltuk, amely hét megküzdési képességet különít el.

3. táblázat. Az ACSI sportolói megküzdés kérdőív által mért eredmények leíró statisztikája és reliabilitása

\begin{tabular}{|c|c|c|c|c|c|c|c|}
\hline Változó & $\mathbf{N}$ & Itemek & Min. & Max. & $\mathbf{M}$ & SD & $\begin{array}{c}\text { Megbízhatósági } \\
\text { mutató }\end{array}$ \\
\hline $\begin{array}{c}\text { Kudarccal való } \\
\text { megküzdés }\end{array}$ & 65 & 4 & 3 & 12 & 7,55 & 2,26 & 0,64 \\
\hline Edzhetőség & 65 & 4 & 3 & 12 & 8,28 & 2,05 & 0,65 \\
\hline Koncentráció & 65 & 4 & 3 & 12 & 8,97 & 2,06 & 0,78 \\
\hline $\begin{array}{c}\text { Magabiztosság és } \\
\text { teljesítménymotiváció }\end{array}$ & 65 & 4 & 5 & 12 & 9,68 & 1,76 & 0,52 \\
\hline $\begin{array}{c}\text { Célok megfogalmazása és } \\
\text { mentális felkészültség }\end{array}$ & 65 & 4 & 1 & 12 & 7,48 & 2,41 & 0,69 \\
\hline $\begin{array}{c}\text { Nyomás alatti } \\
\text { teljesítmény }\end{array}$ & 65 & 4 & 0 & 12 & 8,95 & 2,17 & 0,76 \\
\hline \begin{tabular}{c} 
Szorongásmentesség \\
\hline
\end{tabular} & 65 & 3 & 0 & 9 & 5,30 & 2,10 & 0,72 \\
\hline
\end{tabular}

Ahogy a harmadik táblázat is mutatja jelentős eltérések nem vehetőek észre a hét kategória között, de megállapítható, hogy a profi magyar jégkorongozók legkevésbé mentesek a szorongástól, habár magabiztosak és magas teljesítménymotivációval rendelkeznek. Géczi és mtsai (2008) tanulmányában a felnőtt jégkorongozók a legmagasabb pontszámot a nyomás alatti teljesítmény és a szorongásmentesség alskálán érték el. A nyomás alatti teljesítményen mutatott pontszám a mi esetünkben is magasnak mondható $(M=8,95)$. A szorongásmentesség alskála esetében kizártunk egy itemet, hiszen ezáltal a megbízhatósági mutató 0,64-ről 0,73-ra nőtt. 


\section{A feltételezések vizsgálata}

Első hipotézisünk (H1) így szól: A neuroticitás negatívan, míg az adaptív személyiségjegyek (extraverzió, lelkiismeretesség, nyitottság) pozitívan jelzik előre a hivatásos magyar jégkorongozók stressz állapotát. Az általunk használt személyiség kérdőív a Big5 modell öt faktorát vizsgálja (neuroticitás, extraverzió, nyitottság, együttműködés, lelkiismeretesség). A stressz állapotot pedig két szinten mértük az általános stressz, tehát a mindennapi stressz-szintet, valamint a sport-specifikus stressz, ami csak a sportból, jelen esetben a jégkorongból, származó stresszhelyzeteket foglalja magába. Emellett általános és sport-specifikus regenerációt is mertünk. A személyiségvonások hatását a stressz állapotra többszörös lineáris regresszióval vizsgáltuk.

4. táblázat. Személyiségjegyek együttes előrejelző hatása a stresszre

\begin{tabular}{|c|c|c|c|c|c|c|c|c|}
\hline & $\mathrm{R}$ & $\mathrm{R}^{2}$ & Adjusted $\mathrm{R}^{2}$ & SD & $\mathrm{df}$ & M & F & $\mathrm{p}$ \\
\hline \multirow{3}{*}{$\begin{array}{c}\text { Általános } \\
\text { stressz }\end{array}$} & \multirow{3}{*}{0,50} & \multirow{3}{*}{0,25} & \multirow{3}{*}{0,18} & \multirow{3}{*}{4,07} & 5 & 63,57 & 3,84 & $<0,01^{*}$ \\
\hline & & & & & 59 & 16,55 & & \\
\hline & & & & & 64 & & & \\
\hline \multirow{3}{*}{$\begin{array}{l}\text { Sport-speci- } \\
\text { fikus stressz }\end{array}$} & \multirow{3}{*}{0,37} & \multirow{3}{*}{0,14} & \multirow{3}{*}{0,06} & \multirow{3}{*}{4,02} & 5 & 29,63 & 1,84 & 0,12 \\
\hline & & & & & 59 & 16,13 & & \\
\hline & & & & & 64 & & & \\
\hline
\end{tabular}

* szignifikáns modell

Ahogy a negyedik táblázat is szemlélteti, a modell szignifikáns előrejelzést mutat az általános stressz esetében $(F(5,59)=3,84, p<0,01)$. Az általános stressz-szintben történő $18 \%$-os változását a személyiség tényezőbeli változások magyarázzák. A sport-specifikus stressz esetében nem mutat szignifikáns modellt a regresszió analízis.

5. táblázat. Személyiségtényezők előrejelző az általános stresszre

\begin{tabular}{|c|c|c|c|c|c|}
\hline & $\mathrm{B}$ & $\mathrm{SD}$ & $\nabla$ & $\mathrm{t}$ & $\mathrm{p}$ \\
\hline Neuroticitás & 0,30 & 0,09 & 0,48 & 3,16 & $<0,01^{*}$ \\
\hline Extraverzió & $-0,06$ & 0,13 & $-0,06$ & $-0,47$ & 0,64 \\
\hline Nyitottság & $-0,04$ & 0,10 & $-0,05$ & $-0,43$ & 0,67 \\
\hline Együttmúködés & 0,02 & 0,11 & 0,02 & 0,17 & 0,87 \\
\hline Lelkiismeretesség & 0,02 & 0,12 & 0,02 & 0,14 & 0,89 \\
\hline
\end{tabular}

* szignifikáns hatás

A prediktorok közül egyedüli szignifikáns elörejelző hatása a neuroticitásnak $(\beta=0,48)$ van, míg a többi prediktor nem mutat lényeges eredményt (lásd: 5. táblázat.).
Továbbá megvizsgáltuk a személyiségtényezők hatását az általános és sport-specifikus regenerációt illetően. 
6. táblázat. Személyiségjegyek hatása a regenerációra

\begin{tabular}{|c|c|c|c|c|c|c|c|c|}
\hline & $\mathrm{R}$ & $\mathrm{R}^{2}$ & $\begin{array}{c}\text { Adjusted } \\
\mathrm{R}^{2}\end{array}$ & SD & $\mathrm{df}$ & M & $\mathrm{F}$ & $\mathrm{p}$ \\
\hline \multirow{3}{*}{$\begin{array}{l}\text { Általános } \\
\text { regeneráció }\end{array}$} & \multirow{3}{*}{0,48} & \multirow{3}{*}{0,23} & \multirow{3}{*}{0,16} & \multirow{3}{*}{3,08} & 5 & 33,36 & 3,60 & $<0,01^{*}$ \\
\hline & & & & & 59 & 9,51 & & \\
\hline & & & & & 64 & & & \\
\hline \multirow{3}{*}{$\begin{array}{c}\text { Sport- } \\
\text { specifikus } \\
\text { regeneráció }\end{array}$} & \multirow{3}{*}{0,64} & \multirow{3}{*}{0,40} & \multirow{3}{*}{0,35} & \multirow{3}{*}{5,80} & 5 & 269,44 & 8 & $<0,01^{*}$ \\
\hline & & & & & 59 & 33,70 & & \\
\hline & & & & & 64 & & & \\
\hline
\end{tabular}

* szignifikáns modell

A 6. táblázat adatai alapján elmondható, hogy a modell mind az általános regeneráció $(\mathrm{F}(5,59)=3,50, \mathrm{p}<0,01)$, mind a sport-specifikus regeneráció $(\mathrm{F}(5,59)=8, \mathrm{p}<0,01)$ esetén szignifikáns predikciót mutat. Az általános regenerációban bekövetkező változást 16\%-ban, a sport-specifikus regenerációban bekövetkező változást pedig 35\%ban szabályozzák a személyiség tényezők.

7. táblázat. Személyiségtényezők hatása az általános és sport-specifikus regenerációra

\begin{tabular}{|c|c|c|c|c|c|c|c|c|c|c|}
\hline & \multicolumn{4}{|c|}{ Általános regeneráció } & \multicolumn{5}{c|}{ Sport-specifikus regeneráció } \\
\hline & $\mathrm{B}$ & $\mathrm{SD}$ & $\mathrm{B}$ & $\mathrm{t}$ & $\mathrm{p}$ & $\mathrm{B}$ & $\mathrm{SD}$ & $\beta$ & $\mathrm{t}$ & $\mathrm{p}$ \\
\hline Neuroticitás & $-0,05$ & 0,07 & $-0,11$ & $-0,69$ & 0,49 & $-0,03$ & 0,13 & $-0,03$ & $-0,20$ & 0,84 \\
\hline Extraverzió & 0,13 & 0,10 & 0,17 & 1,30 & 0,20 & 0,52 & 0,18 & 0,32 & 2,84 & $<0,01^{*}$ \\
\hline Nyitottság & $-0,06$ & 0,07 & $-0,10$ & $-0,83$ & 0,41 & $-0,01$ & 0,14 & $-0,01$ & $-0,05$ & 0,96 \\
\hline Együttmúlködés & 0,04 & 0,08 & 0,06 & 0,53 & 0,60 & 0,03 & 0,15 & 0,02 & 0,22 & 0,83 \\
\hline Lelkiismeretesség & 0,16 & 0,09 & 0,29 & 1,86 & 0,07 & 0,49 & 0,16 & 0,41 & 2,96 & $<0,01^{*}$ \\
\hline
\end{tabular}

* szignifikáns hatás

A személyiségjegyeket külön megvizsgálva, az általános regenerációs modellben egyik sem mutat jelentős előrejelzést, míg a sport-specifikus regenerációt tekintve az extraverzió $(\mathrm{t}=2,96, \mathrm{p}<0,01)$ és a lelkiismeretesség $(\mathrm{t}=-2,85, \mathrm{p}<0,01)$ pozitív prediktorok voltak. Ahogy a hatodik táblázat adatai is szemléltetik, a sport-specifikus regeneráció esetében beszélhetünk legerősebb modellről az öszszes közül, hiszen 35\%-os magyarázó erővel bír.

Ezekből az eredményekből arra a megállapításra jutottunk, hogy a neurotikus személyiségvonás a hivatásos magyar jégkorongozók esetében negatív előrejelző erővel bír az általános stressz-szintre. Sport-specifikus stressz és az általános regeneráció esetében nem sikerült szignifikáns hatást feltárnunk a személyiségtényezők tekintetében. Ellenben a sport-specifikus regenerációval, ahol megállapítottuk, hogy mind a lelkiismeretesség, mind az extraverzió a sport-specifikus regenerációt. Összességében jelen kutatás eredményei részben igazolják 
az első hipotézisünket, hiszen a neuroticitás valóban negatív hatással van a magyar hivatásos profi jégkorongozók stressz állapotára, azonban az adaptív személyiségjegyek esetében nem tudtunk releváns következtetésre jutni.

A második hipotézisünk (H2) esetében feltételezzük a következőt: Különbség van az átlagon aluli és átlagon felüli általános és sport-specifikus stresszszinttel rendelkező sportolók között megküzdési stratégiáik mentén. A megküzdési stratégiák mérésére az Athletic Coping Skills Inventory nevezetű eszközt használtuk, amely 7 megküzdési képességet mér és kifejezetten sportolókra fejlesztették ki. A résztvevőket statisztikai átlag alapján bontottuk két csoportra mind az általános, mind a sport-specifikus stressz esetében. A Kruskal-Wallispróbát alkalmaztuk, hiszen a vizsgálati minta nem követ normális eloszlást. Ez egy olyan nem-parametrikus eljárás, amely lehetővé teszi a csoportok közötti eltérések feltárását (Szokolszky, 2004).

8. táblázat. Megküzdési képességek és az általános stressz csoportok összehasonlításának eredménye

\begin{tabular}{|c|c|c|c|c|c|c|}
\hline Megküzdési képességek & $\begin{array}{l}\text { Általános } \\
\text { stressz-szint }\end{array}$ & $\mathrm{N}$ & $\begin{array}{l}\text { Rang } \\
\text { átlag }\end{array}$ & df & $\mathrm{Chi}^{2}$ & $\mathrm{p}$ \\
\hline \multirow{2}{*}{$\begin{array}{l}\text { Kudarccal való } \\
\text { megküizdés }\end{array}$} & Átlag feletti & 30 & 27,10 & \multirow{2}{*}{1,00} & \multirow{2}{*}{5,54} & \multirow{2}{*}{$0,02^{*}$} \\
\hline & Átlag alatti & 35 & 38,06 & & & \\
\hline \multirow{2}{*}{ Edzhetőség } & Átlag feletti & 30 & 28,40 & \multirow{2}{*}{1,00} & \multirow{2}{*}{3,39} & \multirow{2}{*}{0,67} \\
\hline & Átlag alatti & 35 & 36,94 & & & \\
\hline \multirow{2}{*}{ Koncentráció } & Átlag feletti & 30 & 30,48 & \multirow{2}{*}{1,00} & \multirow{2}{*}{1,02} & \multirow{2}{*}{0,31} \\
\hline & Átlag alatti & 35 & 35,16 & & & \\
\hline \multirow{2}{*}{$\begin{array}{l}\text { Magabiztosság és } \\
\text { teljesítménymotiváció }\end{array}$} & Átlag feletti & 30 & 28,30 & \multirow{2}{*}{1,00} & \multirow{2}{*}{3,56} & \multirow{2}{*}{0,60} \\
\hline & Átlag alatti & 35 & 37,03 & & & \\
\hline \multirow{2}{*}{$\begin{array}{l}\text { Célok megfogalmazása } \\
\text { és mentális felkészültség }\end{array}$} & Átlag feletti & 30 & 31,92 & \multirow{2}{*}{1,00} & \multirow{2}{*}{0,19} & \multirow{2}{*}{0,67} \\
\hline & Átlag alatti & 35 & 33,93 & & & \\
\hline \multirow{2}{*}{$\begin{array}{l}\text { Nyomás alatti } \\
\text { teljesítmény }\end{array}$} & Átlag feletti & 30 & 30,22 & \multirow{2}{*}{1,00} & \multirow{2}{*}{1,25} & \multirow{2}{*}{0,26} \\
\hline & Átlag alatti & 35 & 35,39 & & & \\
\hline \multirow{2}{*}{ Szorongásmentesség } & Átlag feletti & 30 & 25,50 & \multirow{2}{*}{1,00} & \multirow{2}{*}{8,97} & \multirow{2}{*}{$<0,01^{*}$} \\
\hline & Átlag alatti & 35 & 39,43 & & & \\
\hline
\end{tabular}

* szignifikáns különbség

A 8. táblázat jól szemlélteti, hogy a megküzdési képességek terén két esetben beszélhetünk szignifikáns különbségről az átlag feletti és az átlag alatti általános stressz-szintet nézve. Az egyik ilyen megküzdési stratégia a kudarccal való megküzdés $(\mathrm{p}=0,02)$, amely esetében azok a sportolók, akik kevésbé stresszesek $(38,06)$ magasabb pontot érték el, mint azok, akik stresszesebbek $(27,10)$. A szorongásmentesség esetében is hasonlóan szignifikáns különbség $(\mathrm{p}<0,01)$ fedezhető fel. A kudarccal való megküzdéshez az átlag alatti stressz-szinttel rendelkezők kevésbé szoronganak $(39,43)$, mint az átlag feletti stressz-szinttel rendelkező $(25,50)$ jégkorongozók. Továbbá látható a 8. táblázatban, hogy minden megküzdési képesség esetében nagyobb pontszámot értek el a kevésbé stresszes jégkorongozók, mint a stresszesebb társaik, azonban csak az említett két esetben beszélhetünk szignifikáns különbségekről.

A sport-specifikus stressz esetében is hasonló stratégiát alkalmaztunk. Az eredményeket a 9. táblázat mutatja be. 
9. táblázat. Megküzdési képességek és a sport-specifikus stressz csoportok összehasonlításának eredménye

\begin{tabular}{|c|c|c|c|c|c|c|}
\hline Megküzdési képességek & $\begin{array}{l}\text { Sport-spe- } \\
\text { cifikus } \\
\text { stressz-szint }\end{array}$ & $\mathrm{N}$ & $\begin{array}{l}\text { Rang } \\
\text { átlag }\end{array}$ & df & $\mathrm{Chi}^{2}$ & $\mathrm{p}$ \\
\hline \multirow{2}{*}{$\begin{array}{l}\text { Kudarccal való } \\
\text { megküizdés }\end{array}$} & Átlag feletti & 23 & 30,67 & \multirow{2}{*}{1,00} & \multirow{2}{*}{0,56} & \multirow{2}{*}{0,46} \\
\hline & Átlag alatti & 42 & 34,27 & & & \\
\hline \multirow{2}{*}{ Edzhetőség } & Átlag feletti & 23 & 24,59 & \multirow{2}{*}{1,00} & \multirow{2}{*}{7,24} & \multirow{2}{*}{$<0,01^{*}$} \\
\hline & Átlag alatti & 42 & 37,61 & & & \\
\hline \multirow{2}{*}{ Koncentráció } & Átlag feletti & 23 & 21,50 & \multirow{2}{*}{1,00} & \multirow{2}{*}{13,59} & \multirow{2}{*}{$<0,01^{*}$} \\
\hline & Átlag alatti & 42 & 39,30 & & & \\
\hline \multirow{2}{*}{$\begin{array}{l}\text { Magabiztosság és } \\
\text { teljesítménymotiváció }\end{array}$} & Átlag feletti & 23 & 27,20 & \multirow{2}{*}{1,00} & \multirow{2}{*}{3,47} & \multirow{2}{*}{0,06} \\
\hline & Átlag alatti & 42 & 36,18 & & & \\
\hline \multirow{2}{*}{$\begin{array}{l}\text { Célok megfogalmazása } \\
\text { és mentális felkészültség }\end{array}$} & Átlag feletti & 23 & 27,67 & \multirow{2}{*}{1,00} & \multirow{2}{*}{2,88} & \multirow{2}{*}{0,09} \\
\hline & Átlag alatti & 42 & 35,92 & & & \\
\hline \multirow{2}{*}{$\begin{array}{l}\text { Nyomás alatti } \\
\text { teljesítmény }\end{array}$} & Átlag feletti & 23 & 25,54 & \multirow{2}{*}{1,00} & \multirow{2}{*}{5,75} & \multirow{2}{*}{$0,02^{*}$} \\
\hline & Átlag alatti & 42 & 37,08 & & & \\
\hline \multirow{2}{*}{ Szorongásmentesség } & Átlag feletti & 23 & 30,78 & \multirow{2}{*}{1,00} & \multirow{2}{*}{0,50} & \multirow{2}{*}{0,48} \\
\hline & Átlag alatti & 42 & 34,21 & & & \\
\hline
\end{tabular}

* szignifikáns különbség

A sport-specifikus stressz-szint alapján való csoportosítást figyelembe véve arra az eredményre jutottunk, hogy az edzhetőség $(\mathrm{p}<0,01)$, a koncentráció $(\mathrm{p}<0,01)$ és a nyomás alatti teljesítmény $(\mathrm{p}=0,02)$ az a három megküzdési képesség, amely szignifikáns különbséget mutat az átlag alatti és az átlag feletti sport-specifikus stressz esetében. Minden esetben az átlag alatti sport-specifikus stressz-szinttel rendelkező hivatásos magyar jégkorongozók értek el a magasabb értékeket a megküzdési stratégiák terén (lásd: 9. táblázat), azonban szignifikáns különbség csak az előbb említett három esetben fedezhető fel.

Öt specifikus megküzdési stratégia terén sikerült feltárnunk szignifikáns különbséget az általános és sport-specifikus stressz alapján. Ebből két megküzdési módszer a szorongásmentesség $(\mathrm{d}=0,76)$ és a koncentráció $(\mathrm{d}=0,99)$ igen magas hatással van a professzionális magyar jégkorongozók stressz állapotára, amit a Cohen-féle d érték kiszámításának segítségével tudtunk meg. A második hipotézisünket az eredményeink alapján alá tudjuk támasztani, hiszen több megküzdési stratégia is szignifikáns különbséget mutat az átlag alatti és feletti stressz-szinttel rendelkező hivatásos magyar jégkorongozók körében.

\section{Következtetések}

Jelen kutatás legfóbb célja az volt, hogy megállapítsuk bizonyos pszichológiai konstruktumok (stressz, személyiség, megküzdési stratégiák) hatását a hivatásos profi magyar jégkorongozókra.

A személyiség esetében az ötfaktoros modellt használtuk, amely a neuroticitás, extraverzió, nyitottság, együttműködés és a lelkiismeretesség skálákat tartalmazta. A feltételezésünk az volt, hogy a Big5 modellben leírt személyiség tényezők előrejelzik a hivatásos jégkorongozók megélt stresszszintjét. A neuroticitás negatív előrejelzést mutat a stresszre. Ez azt jelenti, hogy a magas neuroticitás szint magas stressz-szinttel jár együtt. A lelkiismeretesség és az extraverzió viszont pozitívan jelzi előre a 
sport-specifikus regenerációt. A lelkiismeretes sportolókra jellemző, hogy rendszerezettek, nehéz célokat tűznek ki maguk elé és mindent megtesznek, hogy azokat elérjék. Ezek a jellemzők valószínűleg segítik a regenerációt, mert a sportoló tudja, hogy mindent megfog tenni azért, hogy minél hamarabb regenerálódjon, és maximális teljesítményre legyen képes. De ha ez sem volna elég, akkor könnyebben tudja elfogadni az esetleges kudarc élményt és megtud vele birkózni. Ugyanakkor további kutatások szükségesek annak megállapítására, hogy van-e okokozati kapcsolat az említett tényezők között.

Hasonlóan, az extrovertált emberek általában nagyon élénkek, aktívak és társaságkedvelőek. Valószínűsíthető, hogy ez a személyiségjegy azért jelzi elöre a regenerációt, mert ezek a sportolók könynyebben tudják kezelni az esetleges sérüléseket, ha minél több emberhez fordulhatnak és kikérhetik7 a véleményüket, tanácsukat. Korábbi kutatásokhoz viszonyítva hasonló eredményeket kaptunk a hivatásos magyar jégkorongozó mintán. Magnus és mtsai (1993) eredményeit részben a jelen tanulmány eredményei is alátámasztják, hiszen hasonlóan az általuk végzett kutatáshoz mi is azt az eredményt kaptuk, hogy a neuroticitás negatív hatással van a stresszre. Természetesen a személyiségvonásokon kívül egyéb tényezők is szerepet játszanak a hivatásos jégkorongozók stresszhelyzetét és regenerációját illetően. Tóth és Szabó (2019) megállapította például, hogy a belső motiváció pozitív együttjárást mutat a stressz-mentességgel, míg a motivációmentesség negatívat.

A megküzdési stratégiáknál 7 specifikus sportolói megküzdési képességet vizsgáltunk: kudarccal való megküzdés, edzhetőség, koncentráció, célok megfogalmazása és mentális felkészültség, magabiztosság és teljesítménymotiváció, nyomás alatti teljesítmény és szorongásmentesség. Jelen kutatásban azt vizsgáltuk, hogy az alacsonyabb stressz-szintet mutató hivatásos magyar jégkorongozók különböznek-e a megküzdés terén, mint azoktól a társaiktól, akik magasabb stressz-szinttel rendelkeznek. Az általános stresszt tekintve jelentős különbség mutatkozik a kudarccal való megküzdés és a szorongásmentesség terén. Ezekből az eredményekből arra a következtetésre jutottunk, hogy a kisebb stresszszintet mutató jégkorongozók lelkesebbek és pozitívabbak maradnak, akkor is ha esetleg kudarc éri őket és sokkal inkább tudják kontrollálni a kudarcot és gyorsabban képesek átvészelni ezt az állapotot.
Továbbá fontos szerepe van a szorongásmentességnek is, ami leginkább az aggódásmentességet és a mások nem releváns véleményének figyelmen kívül hagyását foglalja magában. A sport-specifikus stresszt tekintve három megküzdési stratégiát kell kiemelni, mégpedig az edzhetőséget, a koncentrációt és a nyomás alatti teljesítményt. Orlick és Pattrington (1988) is fontosnak találta a nyomás alatti jó teljesítményt, hiszen tanulmányuk szerint a sportolói sikeresség egyik kulcsa lehet ez a tényező. Ebből adódóan fontos szerepet játszik a stressz kezelésében az, hogy egy jégkorongozó mennyire képes fenntartani a fókuszát olyan szituációkban is, amikor nyomás alatt van vagy egy nem várt kellemetlen jelenséggel találkozik, valamint hogyan reagál az esetleges kritikákra. Véleményünk szerint ezek a specifikus sportolói megküzdési képességek, amelyek jelentős hatással vannak a sportolók stressz állapotára fejleszthetőek, azonban ehhez mindenképpen szükséges a megfelelő szakemberek alkalmazása a magyar jégkorongsportban. Ők segíthetnek a sportolóknak ezeket a képességeiket fejleszteni. Szükségesek még a további kutatások, melyek mélyebb szinten célozzák ezt vizsgálni.

Összességében úgy gondoljuk, hogy jelen kutatás azt szemlélteti, hogy szükséges lehet akár egy olyan specifikus stressz menedzsment program kidolgozása, ami konkrét területekre helyezi a hangsúlyt, mint például a megküzdési képességek vagy a stresszkeltő személyiségjegyek változtatása. Ehhez természetesen szükséges lehet jelen tanulmány továbbfejlesztése, valamint további vizsgálatok magyar sportolókon. Véleményünk szerint az egyik ilyen továbbfejlesztési lehetőség lehet a nagyobb mintán való vizsgálat elvégzése, akár más sportágak képviselőinek a bevonásával, valamint jelen pszichológiai jelenségek összehasonlítása egyéni, illetve csapatsportok területén.

\section{Felhasznált irodalom}

1. Aamodt, M. G. (2010): Industriall Organizational Psychology. Cengage Learning, Wadsworth.

2. Afshar, H., Roohafza, H. R., Keshteli, A. H., Mazaheri, M., Feizi, A., Adibi, P. (2015): The association of personality traits and coping styles according to stress level. Journal of research in medical sciences: the official journal of Isfahan University of Medical Sciences, 20.4, 353-358. 
3. Anshel, M. és Anderson, D. (2002): Coping with acute stress in sport: Linking athletes coping style, coping strategies, affect, and motor performance. Anxiety, Stress \& Coping: An International Journal 15. 2, 193-209.

4. Cole, M. és Cole, R. S. (1997): Fejlödéslélektan. Osiris Kiadó, Budapest.

5. Costa Jr, P. T., \& McCrae, R. R. (1992): Four ways five factors are basic. Personality and Individual Differences 13.653-665.

6. Costa Jr, P. T., \& McCrae, R. R. (2003). Personality in adulthood: A five-factor theory perspective (2nd ed.). Guilford Press, New York.

7. Costa, P. T. \& Jr., McCrae, R. R. (2008): The Revised NEO Personality Inventory (NEO-PI-R). In: Boyle, G. J,. Matthews, G., Saklofske, D. H. (Eds.), The SAGE handbook of personality theory and assessment, Vol. 2. Personality measurement and testing, 179198. Sage Publications, Thousand Oaks.

8. Crocker, E. R. P., Tamminen, K. A. és Gaudreau, P. (2015): Coping in sport. In S. Hanton \& S. Mellalieu (Eds.), Contemporary advances in sport psychology: A review (pp. 2867). Routledge, New York.

9. Dumitru, V. M. és Cozman, D. (2012): The relationship between stress and personality factors. Human \& Veterinary Medicine 4, 34-39.

10. Géczi G., Bognár J., Tóth L., Sipos K. és Fügedi B. (2008): Anxiety and Coping of Hungarian National Ice Hockey Players. International Journal of Sports Science and Coaching 3. 2, 277-285.

11. Goldberg, L. R. (1990): An alternative „description of personality": The Big-Five factor structure. Journal of Personality and Social Psychology 59. 6, 1216-1229.

12. Kallus, W. és Kellmann, M. (2016): RESTQ: The Recovery-Stress Questionnaires. Pearson, Frankfurt.

13. Kristiansen, E., Murphy, D. és Roberts, G. C. (2012): Organizational stress and coping in U.S. professional soccer. Journal of Applied Sport Psychology 24. 207-223.

14. Kyprianou, P., Sipos K. és Stravros, S. (2009): Sportolói megküzdési stratégiák és versenyzéssel kapcsolatos szorongás vizsgálata ciprusi labdarúgóknál. Magyar Sporttudományi Szemle 10. 37, 7-10.
15. Lazarus, R.S., \& Folkman, S. (1984): Stress, appraisal and coping. New York: Springer.

16. Maddison, R., Prapavessis, H. A. (2005): Psychological approach to the prediction and prevention of athletic injury. Journal of Sport Exercise Psychology 27. 289-310.

17. Magnus, K., Diener, E., Fujita, F., Pavot, W. (1993): Extraversion and neuroticism as predictors of objective life events: A longitudinal analysis. Journal of Personality and Social Psychology 65. 5, 1046-1053.

18. Nicholls, R. A., Polman, C. J. R., Morley, D. és Taylor, J. N. (2009): Coping and Coping Effectiveness in Relation to a Competitive Sport Event: Pubertal Status, Chronological Age, and Gender Among Adolescent Athletes. Journal of Sport and Exercise Psychology 31. 299-317.

19. Novotny, L. és Petrak, B. (1983): Characteristics of junior and schoolboy ice-hockey players. International Journal of Sport Psychology 1. 15-26.

20. Orlick, T. és Partington, J. (1988): Mental skills to excellence. Sport Psychologist 2. 105-130.

21. Piedmont, L. R., Hill, C. D. és Blanco, S. (1997): Predicting athletic performance using the five-factor model of personality. Personality and Individual Differences 27. 769-777.

22. Sági A.,Velenczei A. és Géczi G. (2012): Utánpótláskorú válogatott jégkorongozó és birkózó fiúk pszichológiai vizsgálata. Magyar Sporttudományi Szemle 13. 52, 31-37.

23. Selye H. (1950): Stress and the general adaptation syndrome. British Medical Journal, 1. 4667, 1383-1392.

24. Smith, R.E., Schutz, R.W., Smoll, F.L. és Ptacek, J.T. (1995): Development and validation of a multidimensional measure of sport-specific psychological skills: The Athletic Coping Skills Inventory-28. Journal of Sport and Exercise Psychology 17. 379-415

25. Szokolszky Á. (2004). Kutatómunka a pszichológiában. Osiris Kiadó, Budapest.

26. Tóth L., Géczi G., Sipos K. és Bognár J. (2010): Psychological characterics of different age-groups of Hungarian national ice hockey players. KALOKAGATHIA 48. 91-102.

27. Tóth R. és Szabó K. (2019): Hivatásos magyar jégkorongozók stresszhelyzetének vizsgálata a motiváció tükrében. Magyar Sporttudományi Szemle 20. 82, 20-27. 